\title{
PENGETAHUAN RISIKO KEHAMILAN DENGAN FREKUENSI KUNJUNGAN ANC PADA IBU HAMIL DI PUSKESMAS BANJARAN KABUPATEN MAJALENGKA
}

\author{
${ }^{1}$ Puput Puspita Sari, ${ }^{2}$ Wiwin Mintarsih P, \& ${ }^{3}$ Siti Patimah \\ 1,2, 3Jurusan Kebidanan Poltekkes Kemenkes Tasikmalaya
}

\begin{abstract}
Abstrak
Penelitian ini bertujuan untuk mengetahui hubungan antara pengetahuan ibu hamil tentang risiko kehamilan dengan frekuensi kunjungan ANC di wilayah Puskesmas Banjaran Kabupaten Majalengka tahun 2017.Metode yang digunakan adalah metode Survey Analitik dengan pendekatan Cross Sectional. Instrumen penelitian menggunakan kuesioner. Teknik pengambilan sampel penelitian dengan menggunakan Accidental Sampling dengan jumlah sampel sebanyak 70 ibu hamil yang datang ke Posyandu dengan usia kehamilan di trimester III.Kesimpulan dari penelitian ini yaitu sebagian besar pengetahuan ibu hamil terhadap risiko kehamilan dikategorikan cukup yaitu sebesar $44.2 \%$ dan sebagian besar frekuensi kunjungan ANC sesuai standar yaitu sebesar $54.2 \%$. Hasil penelitian menunjukan bahwa ada hubungan yang signifikan antara pengetahuan ibu hamil tentang risiko kehamilan dengan frekuensi kunjungan ANC di wilayah Puskesmas Banjaran Kabupaten Majalengka dengan $p$ value sebesar 0,005 .
\end{abstract}

Kata Kunci: Kunjungan ANC, Pengetahuan, Risiko kehamilan

\begin{abstract}
Abstrac
This study aimed at knowing the correlation between the pregnant women's knowledge about pregnancy risk and the frequency of ANC visits in the area of Public Health Centre of Banjaran in Majalengka District in 2017. The method used in this study was an analytic survey with the cross-sectional design. The instrument used was questionnaire. The sample size was 70 pregnant women visiting the Integrated Service Centre with the pregnancy age at trimester III, selected by using accidental sampling. The conclusion of this research was $44.2 \%$ of the respondents had medium knowledge about pregnancy risk and $54.2 \%$ of the respondents' ANC visit frequency was suitable with the standard. The research result showed that there was a significant correlation between the pregnant women's knowledge about pregnancy risk and the frequency of ANC visits in the area of Public Health Centre of Banjaran in Majalengka District with the $p$ value 0.005 .
\end{abstract}

Keywords: ANC visit, Knowledge, Pregnancy risk

\section{PENDAHULUAN}

Pelayanan kesehatan ibu merupakan hal penting yang harus diberikan baik selama masa kehamilan, persalinan ataupun nifas untuk memantau pertumbuhan dan perkembangan ibu dan bayinya dalam keadaan normal. Hal tersebut dikarenakan Angka Kematian lbu (AKI) merupakan salah satu indikator yang peka dalam menggambarkan kesejahteraan masyarakat di suatu Negara (Kemenkes RI, 2014).

Berdasarkan Survei Demografi dan Kesehatan Indonesia (SDKI) tahun 2012 Angka Kematian Ibu di Indonesia sebesar 359 per 100.000 kelahiran hidup. Dengan demikian, untuk dapat membantu dalam mengurangi AKI harus diambil sikap proaktif serta berencana dengan upaya promotif dan preventif sebagai langkah 
pencegahan terjadinya kematian ibu (Manuaba, 2007)

Kematian ibu terjadi akibat berbagai komplikasi dalam kehamilan, persalinan atau periode setelah melahirkan. Komplikasi tersebut disebabkan oleh penyebab langsung dan tidak langsung, penyebab langsung terjadi akibat komplikasi obstetrik atau penyakit kronik yang menjadi lebih berat selama kehamilan. Penyebab langsung yang sering ditemui antara lain perdarahan, eklampsi dan infeksi. Adapun penyebab tidak langsung terjadi akibat penyakit yang telah ada sejak sebelum kehamilan atau penyakit yang timbul selama kehamilan seperti malaria. Komplikasi kehamilan dan persalinan dapat dicegah dengan pemeriksaan kehamilan (Anetanal Care) secara teratur (Romauli, 2011).

Upaya pelayanan kesehatan sebagai upaya pencegahan terjadinya komplikasi dalam kehamilan yang dapat dilakukan adalah dengan melakukan pemerikasaan kehamilan atau Antenatal Care. Manfaat pemeriksaan Antenatal Care adalah untuk mendeteksi dini terjadinya resiko tinggi terhadap kehamilan dan persalinan juga dapat menurunkan angka kematian ibu dan memantau keadaan janin (Padila, 2014).

Kebijakan program Kesehatan Ibu dan Anak (KIA) menyebutkan bahwa kunjungan Antenatal Care paling sedikit 4 kali selama kehamilan, yaitu 1 kali pada trimester I, 1 kali pada trimester II dan 2 kali pada trimester III (Kemenkes RI, 2013). Asuhan standar minimal pelayanan yang harus dilakukan oleh bidan atau tenaga kesehatan adalah dengan "10T" meliputi; Timbang berat badan dan ukur tinggi badan; Pemeriksaan tekanan darah; Nilai status gizi (ukur lingkar lengan atas); Pemeriksaan puncak rahim (tinggi fundus uteri); Tentukan presentasi janin dan denyut jantung janin (DJJ); Skrining status imunisasi Tetanus dan berikan imunisasi Tetanus Toxoid (TT) bila diperlukan; Pemberian tablet zat besi minimal 90 tablet selama kehamilan; Test laboratorium (rutin dan khusus); Tatalaksana kasus; Temu wicara (konseling) termasuk Perencanaan Persalinan dan Pencegahan Komplikasi (P4K) serta KB pasca persalinan (Depkes $\mathrm{RI}, 2009$ ).

Berdasarkan Survei Badan Pusat Statistik (BPS) pada tahun 2013 AKI di Jawa Barat sebesar 83 per 100.000 kelahiran hidup. Angka tersebut menurun sedikit jika dilihat dari AKI pada tahun 2012 sebesar 86,3 per 100.000 kelahiran hidup (POGI Jabar, 2013).

Angka kematian di Kabupaten Majalengka pada tahun 2015 berdasarkan data dari Dinas Kesehatan Kabupaten Majalengka (2016), tercatat sebanyak 20 kasus kematian baik pada kehamilan, persalinan dan nifas. Pada ibu hamil terjadi 5 kasus kematian (25\%), pada ibu melahirkan terjadi 6 kasus kematian (30\%), pada ibu nifas terjadi 9 kasus kematian (45\%) dari 20.314 kelahiran hidup yang sebagian besar terjadi akibat perdarahan dan hipertensi dalam kehamilan.

Cakupan antenatal di Jawa Barat per Kabupaten dan Kota, Kabupaten Majalengka memiliki cakupan pelayanan Antenatal Kunjungan 1 (K1) sekitar 95,78\% dan Antenatal Kunjungan 4 (K4) sekitar $84,67 \%$ pada tahun 2015 (Dinas Kesehatan Majalengka, 2015).

Dari 32 Puskesmas di Kabupaten Majalengka, Puskesmas Banjaran merupakan Puskesmas dengan target cakupan antenatal terendah. Kunjungan Antenatal di Puskesmas Banjaran pada tahun 2015 untuk cakupan Antenatal Kunjungan 1 (K1) hanya mencapai 409 $(90,09 \%)$ ibu hamil dan Antenatal Kunjungan 4 (K4) mencapai 371 (81,72\%) ibu hamil dengan jumlah sasaran ibu hamil 447 orang dengan berbagai masalah resiko kehamilan pada ibu diantaranya dengan penyebab 4 Terlalu (4T) mencapai 64 kasus, anemia dalam kehamilan 23 kasus, Kekurangan Energi Kronik (KEK) 37 kasus dan kasus lain-lain seperti penyakit kronis, kelainan letak dan riwayat kehamilan buruk 23 kasus. (Dinas Kesehatan Majalengka, 2016) 
Pada tanggal 1 September 2016, penulis melakukan wawancara kepada 15 ibu hamil yang mengalami risiko kehamilan dengan pertanyaan bersumber dari buku KIA yang dimiliki oleh ibu hamil. Hasil yang didapat adalah 9 ibu hamil $(60 \%)$ tidak mengetahui tentang risiko kehamilan dan 6 ibu hamil (40\%) mengerti dan memahami mengenai risiko kehamilan. Berdasarkan data tersebut sebagian besar ibu hamil masih kurang mengerti dan memahami tentang risiko kehamilan.

Dari hasil studi pendahuluan dengan metode wawancara tersebut diatas maka peneliti tertarik melakukan penelitian mengenai hubungan pengetahuan risiko kehamilan dengan frekuensi kunjungan ANC pada ibu hamil di Wilayah Puskesmas Banjaran Kabupaten Majalengka.

\section{METODE PENELITIAN}

Metode yang digunakan dalam penelitian ini adalah metode Survei Analitik dengan pendekatan Cross Sectional. Populasi penelitian yaitu ibu hamil dengan usia kehamilan trimester III pada bulan Februari tahun 2017 sebanyak 74 ibu hamil.

Teknik pengambilan sampel dengan secara accidental sampling. Ukuran sampel dalam penelitian ini sebanyak 70 ibu hamil yang telah memenuhi kriteria inklusi, yaitu; lbu hamil yang melakukan pemeriksaan ANC di posyandu setiap desa, Ibu hamil dengan usia kehamilan $\geq$ 32 minggu, Ibu hamil yang bersedia menjadi responden, Ibu hamil yang sehat jasmani dan rohani.

Pengumpulan data didapat pada saat ibu hamil datang ke posyandu dengan usia kehamilan di trimester III pada tanggal 0628 Februari 2017. Untuk data sekunder diperoleh dari hasil data riwayat pemeriksaan kehamilan yang tertulis pada buku KIA ibu hamil.

Hasil pengisisan kuesioner menjadi data yang selanjutnya dipindahkan pada data komputer untuk memudahkan dalam proses pengambilan data. Untuk analisis bivariat, uji yang digunakan untuk mencari hubungan pengetahuan ibu hamil dengan frekuensi kunjungan ANC adalah Uji Chi Square.

\section{HASIL PENELITIAN}

\section{Karakteristik Responden}

Tabel 1. Distribusi Karakteristik Ibu Hamil

\begin{tabular}{lcc}
\hline $\begin{array}{c}\text { Karakteristik } \\
\text { Responden }\end{array}$ & Jumlah & $\begin{array}{c}\text { Persentase } \\
(\%)\end{array}$ \\
\hline Pendidikan & & \\
\hline SD & 16 & $22,9 \%$ \\
SMP & 33 & $47,1 \%$ \\
SMA & 13 & $18,6 \%$ \\
PT & 8 & $11,4 \%$ \\
\hline Usia & & \\
\hline$<20$ Tahun & 9 & $12,9 \%$ \\
20-35 Tahun & 54 & $77,1 \%$ \\
$>35$ Tahun & 7 & $10 \%$ \\
\hline Pekerjaan & & \\
\hline SWASTA & 3 & $4,3 \%$ \\
IRT & 67 & $95,7 \%$ \\
\hline
\end{tabular}

Distribusi karakteristik responden pada tabel 1, dilaporkan bahwa sebagian besar ibu hamil pendidikan terakhir SMP sebanyak 33 orang $(47,1 \%)$. Usia 20-35 tahun sebanyak 54 ibu hamil $(77,1 \%)$ dan sebagian besar pekerjaan ibu hamil adalah ibu rumah tangga sebanyak 67 ibu hamil (95,7\%).

\section{Distribusi Frekuensi berdasarkan Tingkat Pengetahuan}

Tabel 2. Distribusi Tingkat Pengetahuan Ibu Hamil

\begin{tabular}{llcc}
\hline $\begin{array}{c}\text { Tingkat } \\
\text { Pengetahuan }\end{array}$ & Frekuensi & $\begin{array}{c}\text { Persentase } \\
(\%)\end{array}$ \\
\hline - & Baik & 23 & $32,8 \%$ \\
- & Cukup & 31 & $44,2 \%$ \\
- & Kurang & 16 & $22,8 \%$ \\
\hline
\end{tabular}

Tabel 2 menunjukan sebagian besar pengetahuan ibu hamil dikategorikan 
dengan pengetahuan cukup sebanyak 31 ibu hamil $(44,2 \%)$.

\section{Distribusi Frekuensi berdasarkan Kunjungan ANC}

Tabel 3. Distribusi Frekuensi Kunjungan ANC Ibu Hamil

\begin{tabular}{lcc}
\hline Kunjungan ANC & Frekuensi & Presentase \\
\hline - $\begin{array}{l}\text { Sesuai } \\
\text { Standar }\end{array}$ & 38 & $54,2 \%$ \\
- $\begin{array}{l}\text { Tidak Sesuai } \\
\text { Standar }\end{array}$ & 32 & $45,7 \%$ \\
\hline
\end{tabular}

Tabel 3. menunjukan sebagian besar frekunesi kunjungan ANC ibu hamil dikategorikan sesuai standar sebanyak 38 ibu hamil $(54,2 \%)$.

4. Hubungan Pengetahuan Ibu Hamil tentang Risiko Kehamilan dengan Frekuensi Kunjungan ANC di Wilayah Puskesmas Banjaran Kabupaten Majalengka

Tabel 4. Hubungan Pengetahuan Risiko Kehamilan dengan Frekuensi Kunjungan ANC

\begin{tabular}{cccc}
\hline \multirow{2}{*}{ Pengetahuan } & \multicolumn{2}{c}{ Kunjungan } & \multirow{2}{*}{ Jumlah } \\
\cline { 2 - 3 } & Standar & $\begin{array}{c}\text { Tidak } \\
\text { Standar }\end{array}$ & \\
\hline - Baik & $\begin{array}{c}14 \\
(61 \%)\end{array}$ & $\begin{array}{c}9 \\
(3,9 \%)\end{array}$ & 23 \\
\hline - Cukup & $\begin{array}{c}21 \\
(67,7 \%)\end{array}$ & $\begin{array}{c}10 \\
(32,7)\end{array}$ & 31 \\
\hline - Kurang & $\begin{array}{c}3 \\
(18,7 \%)\end{array}$ & $\begin{array}{c}13 \\
(81,5)\end{array}$ & 16 \\
\hline Jumlah & $\begin{array}{c}38 \\
(54.2 \%)\end{array}$ & $\begin{array}{c}32 \\
(45,7 \%)\end{array}$ & 70 \\
\hline
\end{tabular}

Hubungan antara Pengetahuan Ibu Hamil tentang Risiko Kehamilan dengan Frekuensi Kunjungan ANC di Wilayah Puskesmas Banjaran Kabupaten Majalengkadapat dilihat pada tabel 4 dengan hasil uji statistik diperoleh nilai $p=0,005 \quad(\alpha=5 \%)$, maka dapat disimpulkan bahwa $\mathrm{H}_{0}$ diterima artinya ada hubungan yang signifikan antara pengetahuan tentang risiko kehamilan dengan frekuensi kunjungan ANC pada ibu hamil di Wilayah Puskesmas Banjaran Kabupaten Majalengka.

\section{PEMBAHASAN}

Tingkat pendidikan responden yang sebagian besar berpendidikan Sekolah Menengah Pertama (SMP) dengan hasil pengetahuam responden secara keseluruhan sebagian besar cukup. Artinya bahwa masyarakat hanya tahu dan masih kurang memahami dengan suatu materi yang dipelajari, sehingga pendidikan mempengaruhi pemahaman responden terhadap kuesioner yang diberikan. Menurut Notoatmodjo (2010) tingkat pendidikan formal merupakan dasar pengetahuan intelektual yang dimiliki seseorang.

Frekuensi kunjungan ANC ibu hamil dalam melakukan pemeriksaan kehamilan sebagian besar di fasilitas kesehatan seperti ke puskesmas, Bidan Praktik Mandiri (BPM), Posyandu dan Polindes. Namun ditinjau dari data yang masuk, sebagian besar responden tidak melakukan kunjungan ANC adalah pada trimester pertama. Ada beberapa faktor yang mempengaruhi kunjungan ANC responden, diantaranya adalah pengalaman kehamilan sebelumnya. Menurut Lawrence Green (1980) dikutip dalam buku Notoatmodjo (2007) perilaku manusia dipengaruhi oleh beberapa faktor, salah satunya faktor predisposisi (predisposing factor) yang terwujud dalam pengetahuan, sikap, kepercayaan dan keyakinan.

Sebagian besar frekuensi kunjungan ANC dalam penelitian ini adalah sesuai standar dengan pengetahuan yang baik. Keuntungan yang didapat oleh ibu hamil apabila melaksanakan kunjungan ANC sesuai standar adalah ibu dapat melakukan konseling dengan tenaga kesehatan untuk kehamilannya dan ibu diberikan pengetahuan tambahan dengan membaca buku KIA. Menurut Manuaba 
(2010) manfaat dengan melaksanakan kunjungan ANC ibu mendapatkan konseling berupa pemberian nasehat dan petunjuk berbagai masalah yang berkaitan dengan kehamilannya serta berusaha menetapkan penggolongan kehamilan dengan faktor risiko atau risiko tinggi atau menentukan pertolongan persalinan. Semakin tinggi tingkat pengetahuan ibu tentang risiko kehamilan akan berpengaruh pada kesadaran dan kemauan ibu untuk melakukan pemeriksaan ANC.

Sebanyak 14 orang $(23,7 \%)$ ibu hamil berpengetahuan baik dengan pelaksanaan kunjungan ANC tidak sesuai standar. Faktor yang mempengaruhinya adalah dari pengalaman kehamilan sebelumnya yang merasa selalu baik-baik saja walau kehamilan sudah masuk trimester kedua. Menurut Soekanto (2010) pengetahuan juga dapat diperoleh melalui kenyataan (fakta) dengan melihat atau mendengar sendiri, serat melalui alat-alat komunikasi misalnya dengan membaca surat kabar, mendengarkan radio atau melihat televisi. Sehingga dengan akses media tersebut ibu dapat memperoleh informasi tentang risiko kehamilan.

Dari 71 orang ibu hamil melakukan pemeriksaan kehamilan sesuai standar sebanyak 3 orang $(4,3 \%)$ ibu hamil dengan pengetahuan yang kurang. Beberapa faktor yang mempengaruhi yaitu dari pemahaman ibu hamil dilatarbelakangi oleh pendidikan yang masih rendah. Karena pada umunya pengetahuan seseorang dipengaruhi oleh pendidikan yang pernah diterima, semakin tinggi tingkat pendidikan seseorang maka semakin baik tingkat pengetahuan (Notoatmodjo, 2010).

Sebanyak 18 orang $(30,6 \%)$ ibu hamil tidak melaksanakan pemeriksaan kehamilan sesuai standar dan pengetahuan ibu tentang risiko kehamilan kurang. Standar waktu pelayanan antenatal menurut WHO adalah minimal 4 kali kunjungan selama kehamilan. Beberapa faktor yang mempengaruhi kunjungan ibu hamil dalam memperoleh kesehatan antara lain dalam pengambilan keputusan, kepercayaan, fasilitas kesehatan, petugas kesehatan dan sosial ekonomi. Menurut Notoatmodjo (2007) timbulnya perilaku meencegah penyakit didasari oleh pengetahuan dan kesadaran serta sikap yang positif dari individu. Faktor-faktor yang membentuk perilaku meliputi faktor intern yang mencakup pengetahuan, kecerdasan, persepsi, emosi dan motivasi yang berfungsi untuk mengolah rangsangan dari luar, sedangkan faktor ekstern meliputi lingkungan sekitar baik fisik ataupun non fisik seperti iklim, manusia, sosial ekonomi dan kebudayaan.

\section{KESIMPULAN}

Gambaran karakteristik ibu hamil adalah sebagian besar berpendidikan SMP sebanyak 33 orang (47.1\%), usia 20-35 tahun sebanyak 54 orang (77.1\%) dan pekerjaan ibu hamil sebagian besar lbu Rumah Tangga (IRT) sebanyak 67 orang (95.7\%). Sebagian besar pengetahuan ibu hamil terhadap risiko kehamilan dikategorikan dengan pengetahaun cukup sebanyak 31 orang (44.2\%). Sebagian besar frekuensi kunjungan ANC adalah sesuai standar sebanyak 38 orang (54.2\%). Dari hasil penelitian yang sudah dilaksanakan, ada hubungan antara tingkat pengetahuan ibu hamil tentang risiko kehamilan dengan frekuensi kunjungan ANC di wilayah Puskesmas Banjaran Kabupaten Majalengka dengan nilai $p$ value $=0,005$.

\section{DAFTAR PUSTAKA}

Arikunto, S., (2010). Prosedur Penelitian : Suatu Pendekatan Praktik. Edisi Rev. Cetakan ke-14. Jakarta : Rineka Cipta.

Damayanti, Erni., Nur, Winarsih., (2008). Hubungan Tingkat Pengetahuan Ibu Hamil tentang Risiko Kehamilan dengan Kepatuhan Kunjungan Antenatal Care di RSUD Pandan Arang Boyolali. tersedia dalam 
https://www.publikasiilmiah.ums.ac.id; Diakses tanggal 27 Agustus 2016.

Dinas Kesehatan Kabupaten Majalengka, (2015). Profil Kesehatan Kabupaten Majalengka tahun 2015. Majakengka : Dinas Kesehatan Kabupaten Majalengka.

Kemenkes RI., (2012). Pedoman Pelayanan Antenatal Terpadu. Edisi ke-2 : Jakarta

Kemenkes RI., (2013). Buku Saku Pelayanan Kesehatan Ibu di Fasilitas Kesehatan Dasar dan Rujukan. Edisi ke-1 : Jakarta

Kemekes RI., (2014). Infodatin Mother's Day Situasi Keadaan Ibu. Jakarta, tersedia dalam https://www.depkes.go.id; Diakses tanggal 28 September 2016.

Manuaba, Ida A.C., Manuaba, Ida B., Gde F., Manuaba, Ida B.G., (2010). IImu Kebidanan, Penyakit Kandungan dan Keluarga Berencana untuk Pendidikan Bidan. Edisi ke-2. Jakarta : Buku Kedokteran EGC

Notoatmodjo, S., (2007). Promosi Kesehatan dan IImu Prilaku. Jakarta : Rineka Cipta (2010). Metodologi Penelitian Kesehatan. Ed. Rev. Jakarta : Rineka Cipta

Padila, (2014). Buku Ajar Keperawatan Maternitas. Yogyakarta : Nuha Medika

POGI Jabar., (2013). Analisi Data Penyebab Kematian Ibu di Provinsi Jawa Barat tahun 2013 tersedia dalam: https://www.slideshare.net; diakses tanggal 15 September 2016.

Riyanto, A., (2009). Metodologi Penelitian Kesehatan. Yogyakarta : Nuha Medika

Romauli, S., (2011). Buku ASKEB I : Konsep Dasar Asuhan Kehamilan. Yogyakarta : Nuha Medika
Saifuddin, A.B, Adriaansz, G., Winkjosastro, Gulardi H., Waspodo, Djoko., (2009). Buku Acuan Nasional Kesehatan Maternal dan Neonatal. Edisi ke-1. Cetakan ke-5. Jakarta : Bina Pustaka Sarwono Prawirohardjo

Saifuddin, A.B., Rachimhadhi, T., Winkjosastro, G.H., (2010). Buku Ilmu Kebidanan. Edisi ke-4. Cetakan ke-3. Jakarta : Bina Pustaka Sarwono Prawirohardjo

Sudarti., dan Fauziah, A., (2010). Hubungan Tingkat Pengetahuan lbu Hamil tentang ANC dengan Frekuensi Kunjungan ANC di BPS Fajar Samiati, Yogoyudon, Wates, Kulon Progo, Yogyakarta, tersedia dalam https://www.journal.respati.ac.id; Diakses tanggal 27 Agustus 2016

Soekanto, (2010). Pengantar Sosiologi. Jakarta : Rajawali Press

Sujarweni, V.W., (2014). Metodologi Penelitian. Yogyakarta : Pustaka Baru Press

Sukmo, R., Islamudin, R.A., Pamungkas, Imam S.A., (2014). ICE (Intensive Community Empowerment) sebagai Solusi Upaya Mencegah Kenaikan Angka Kematian Ibu (AKI) sebagai Program Percontohan di Wilayah Kelurahan Bangetayu Wetan Kecamatan Genuk Kota Semarang. Jurnal IImiah Mahasiswa. Vol. 4/1, hal 12-17

Walyani, E.S., (2015). Asuhan Kebidanan pada Kehamilan. Yogyakarta : Pustaka Baru Press

Yuliah, R., Yuswanto, T.J.A., (2014). Asuhan Kebidanan Komunitas. Edisi ke-2. Jakarta : Salemba Medika 